\title{
Magnetic damper for aircraft engine D436T
}

\author{
T. V. Gulyaeva*, O. V. Tatarchuk**, L. V. Gulyaeva*** \\ https://doi.org/10.31174/NT2018-158VI18-13 \\ *Zaporizhzhya national technical University, Zaporizhzhya, Ukraine, \\ ${ }^{* *}$ SE "Ivchenko-Progress", Zaporizhzhya, Ukraine \\ ***ZZaporizhzhya national technical University, Zaporizhzhya, Ukraine
}

Paper received 02.01.18; Accepted for publication 08.01.18.

\begin{abstract}
The article discusses the design of a magnetic damper to fix the problem the occurrence of resonance, leading to vibration of the shaft at high speeds. When creating engines of large bypass ratio and large rotor speeds are crucial questions speakers. The most effective means of reducing the level of vibrations and dynamic loads at the nodes of the motors is the use of damper supports. For the final determination of the effectiveness of the type of damper selected and designed for this engine, it is necessary to perform experimental work. When fine-tuning the engine D-436T1 (special examination for the fan wheel) at $5900 \mathrm{rpm}$ fan...6100 rpm had increased engine vibration at frequencies of the rotor due to resonance vibrations of the shaft of the fan. These oscillations were caused by the bending of the shaft of the fan and tapping it into stator and rotor parts of the compressor low pressure. A change in the design of the fan shaft to eliminate resonance was impossible. Domain service fan wheel and fan design coil spring / oil damper was not provided to prevent resonance. To solve the problem of design of a magnetic damper that allows you to change the technology of Assembly of the engine and provide its operation on all modes. The analysis of magnetic materials that can be used in the damper based on the design features and maximize the stiffness of the damper. Analyzed three systems: Sm-Co, Fe-Nd-B and Fe-Nd-C, from which we can conclude that magnetic characteristics of the most printlevel may be the system Fe-Nd-B. At the moment developed the design of the fan shaft with magnetic damper is at the stage of experimental work to determine the effect of magnetic field on the details that surround the damper in the first place, on the parts of the bearing and the efficiency of the damping
\end{abstract}

Keywords: magnetic damper, axial force, radial force, the stiffness of the damper, the coercive force, residual induction.

Introduction. In the aircraft industry the main goal of the developers of turbojet engines is the creation of highly economical and reliable, with low specific gravity propulsion. The life and reliability of modern machines with elements rotating in a large extent depends on the level of vibration, durability of bearings, the magnitude of the dynamic loads caused by rotor imbalance. One of the reasons that causes more vibrations in an aircraft engine, is the increased imbalance of the rotor (or rotors), which can lead to the excitation of one or more critical speeds, vibration of the rotor, and cause the resonance phenomena in the reference design [1].

When you create engines heavily decontrol with large rotor speeds are crucial questions speakers. The most effective means of reducing the level of vibrations and dynamic loads at the nodes of the motors is the use of dampfern supports. Supports of rotor are separate modules, which are included in the constructive force of an engine system. Design dampfer supports very diverse, but regardless of this they have the following main functions:

- to reduce the support stiffness of the rotor, which leads to a change of dynamic elastic system of the engine (this reduces the natural frequency of the system, eliminates resonances in the operating modes);

- the absorption of the vibration energy of the engine dynamic system, turning it into heat, which does not allow to develop large ampltude vibrations, dynamic loads and stresses in engine parts.

Nowadays in aviation engines use three basic types dampfern supports:

- hydrodynamic (oil) damper;

- hydrodynamic (oil) damper and elastic element type "squirrel wheel" (elastic oil damper);

- with elastic ring.

For the final determination of the effectiveness of the type of damper selected and designed for this engine, it is necessary to perform experimental zavodnye work. But since experimental evidence is of high value, it is advisable to use numerical simulation to evaluate variants of the system rotorbearing:

1. Determination of critical speeds redemptive system.

2. The calculation of the system response, steady-on im- balance, i.e., forced oscillations.

3. Methods of assessment of residual unbalance in the rotor.

4. Investigation of the stability of the system rotor-bearing on the basis of the calculation of the critical speed taking into account damping or the application of sustainability criteria.

5. Analysis of the transient unsteady processes or reactions of the rotor to imbalance and impact exciting force and also the study of transients caused by the phenomenon of self-excitation.

Abroad these issues were addressed by many authors in a different setting. In the CIS such researches were considered in the MAI and CIAM. In Ukraine the company "IvchenkoProgress" developed a methodology and software package for the determination of natural frequencies and forms of oscillations of a system of rotors, and also for definition of amplitude-frequency characteristics, which are caused by the response of the system is established on imbalances, on structural friction and viscous friction. To determine the natural frequencies used in the method of initial parameters for systems which have many relations [2,3].

Design features magnetic mounts engine D-436T1. On GP "Ivchenko-Progress" in fine-tuning the engine D-436T1 (special examination for the fan wheel) at $5900 \mathrm{rpm}$ fan...6100 rpm had increased engine vibration at frequencies of the rotor due to resonance vibrations of the shaft of the fan. These oscillations were caused by the bending of the shaft of the fan and tapping it into stator and rotor parts of the compressor low pressure. A change in the design of the fan shaft to eliminate resonance was impossible. Domainservice fan wheel and are available in fan design elastic oil damper was not provided to prevent resonance. To solve the above mentioned problems together with the SE "IvchenkoProgress" according to the agreement on cooperation was tasked to design such a damper that would allow the available geometrical dimensions do not change the technology of Assembly of the engine and provided the performance of the engine during all modes of operation. A separate task was to ensure maximum rigidity of the damper due to the selection of magnetic material with optimal properties [4-7].

On the basis of the foregoing, of the design of the fan 
shaft with a magnetic damper [8-10], which would allow to eliminate the resonance frequency region of the operating range of the engine and to prevent the increase of vibration level. The scheme also had the task of testing the possibility of applying this type of damper as extra support for long shaft engines. Developed the design of the support does not require the traditional oil supply for cooling of the bearing and is devoid of typical defects mevalonic supports (proconsulare, the complexity of the supply and discharge of oil, the complexity of the collection and ensure that special requirements for the bearing).

In Fig. 1 shows the fan shaft of aircraft engine D-436 T1 with magnetic support [5,11].

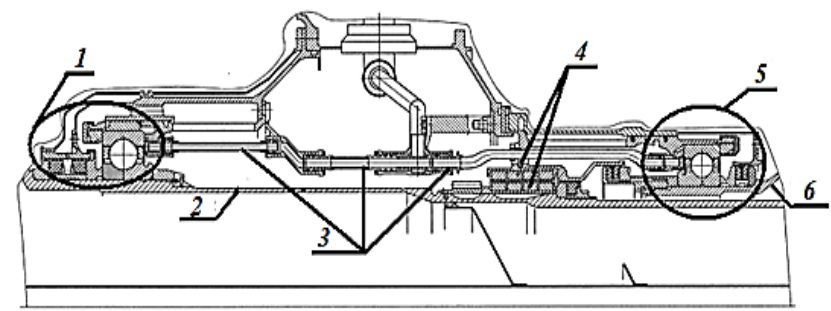

Fig. 1. The fan shaft of aircraft engine D-436 T1 with magnetic bearing: 1 - bearing of the fan, 2 - fan shaft, 3 -the oil feed pipe, 4 - magnetic damper, 5 - bearing the low-pressure compressor, 6 shaft front compressor low pressure.

In Fig. 2 shows the structure of the rings of the rotor and the stator.

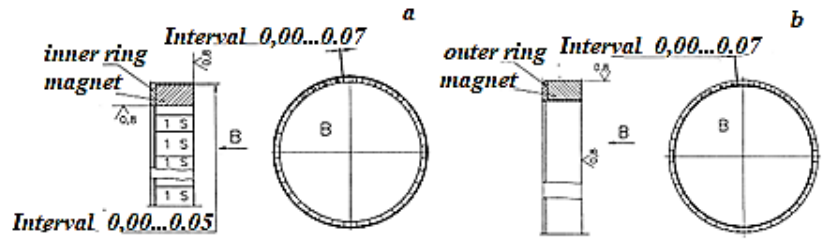

Fig. 2. the Design of the rings of rotor and stator: $a-$ the inner ring with magnets, $\mathrm{b}$ - outer ring with magnets.

Developed magnetic damper consists of a portion that rotates the rotary and stationary part (stator). Rotary part of the magnetic damper consists of a set of radially magnetized sectors gathered in a ring of non-magnetic steel (EP 33-VD) and installed in the cage with magnetom eco steel (EP 609W) of alternating magnetic poles, each pair of segmented rings. The fixed part of the damper is assembled from segments radially magnetized permanent magnets assembled in a ring of non-magnetic steel (EP 33-VD) and installed in the cage with magnetom eco steel (EP 609 - W) of alternating magnetic poles, each pair of segmented rings. Thus, the poles of the magnets of the rotor and stator create a whole range repulsive force. In Fig. 3 shows a bushing with magnets.

Design must provide:

1. The mutual displacement in axial direction by the amount $\mathrm{L}$ of the sleeve with the magnets 1 and sleeve with magnets 2 (Fig. 4).

2. Measurement of axial force Grew and the value of $\mathrm{L}$ when mutual displacement of the sleeve with the magnets 1 and sleeve 2 with magnets (see Fig. 4).

3. The mutual displacement in the radial direction by the amount $d$ of the sleeve with the magnets 1 and sleeve 2 with magnets.

4. Measuring radial forces of $\mathrm{Rad}$ and the value of $\mathrm{d}$ when mutual displacement of the sleeve with the magnets 1 and sleeve 2 with magnets (see Fig. 4).

5 . Rigid fixation of one of the plugs with magnets in the measurement of axial and radial ROS Red forces.

6 . The step width in the measurement of axial and radial forces $-0.1 \mathrm{~mm}$.

7. Needs to be secured and the installation of the hub axle with the magnets 1 and sleeve 2 with magnets in adjacent axes (see Fig. 4).

8. Weight of the subjects and items of equipment should not affect the accuracy of measurement of forces.

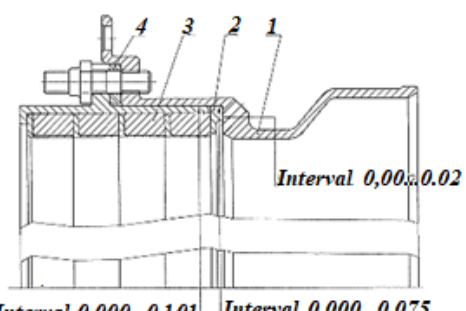

Fig. 3. Bushing with magnets: 1 - sleeve, 2 - ring, 3 - sleeve with magnets, 4 - adjusting ring.

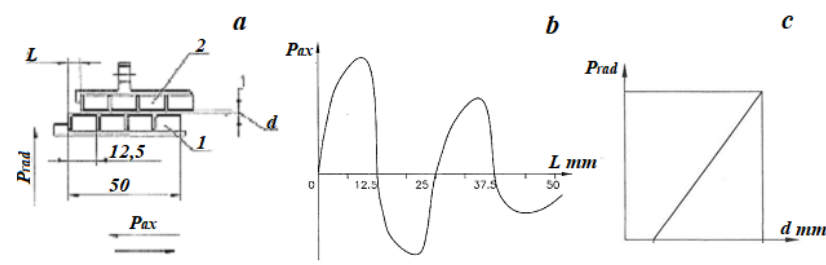

Fig. 4. - Scheme of tests of the magnetic damper: a - Magnetic damper: 1 - inner ring, 2 - ring appearance: $b$ Addiction $\mathrm{P}_{\mathrm{oc}}(\mathrm{L}) ; \mathrm{c}-$ Addiction $\mathrm{P}_{\text {рад }}(\mathrm{d})$;

According to the scheme of the test magnetic damper (see Fig. 4), the value razanajato (axial) forces $\mathrm{P}_{\mathrm{oc}} \geq 1500 \mathrm{~N}$, the value of radial force $\mathrm{Rad} \geq 500 \mathrm{~N}$.

Features choice of permanent magnet material

The requirements that apply to magnetic materials:

- high coercive force;

- low specific weight;

- low cost;

- stable characteristics over a wide temperature range and time;

- sufficient physical and chemical properties;

- high electrical resistance.

The use of permanent magnets with a high value of coercive force, which characterizes the resistance Romagnan arising from the characteristics of the suspension: of the magnet in the field of another magnet. The required values razanajato forces can be achieved provided that there is no significant mutual demagnetization of support elements. This condition is responsible cobalt alloys and composite materials based on alloy Nd-Fe-(b,C). When looking at the second type alloys are also the third condition is low cost compared to cobaltocene alloys. The specific weight of the obtained sintered magnets $-9375 \mathrm{~kg} / \mathrm{m}^{3}$.

High resistance of magnetic materials is necessary to minimize losses from eddy currents generated by the rotation of the shaft.

Also, the design of a magnetic damper was used, known at that time, magnetic material based on the alloy Sm-Co with known characteristics. However, the high cost of the Sm, high energy costs for obtaining cobalt and the need to preserve the basic characteristics of quite a long time does not give them sufficient widespread use. To reduce the cost of such magnets you can use magnets based on alloys of the system Fe-Nd-B and Fe-Nd-C. Table 1 presents comparative characteristics of the magnets of the systems Sm-Co, Fe-Nd- 
$\mathrm{B}$ and $\mathrm{Fe}-\mathrm{Nd}-\mathrm{C}$ (TC - Curie temperature, IS the spontaneous on-magnet, $\mathrm{HA}$ - anisotropy field, (BH)max - the maximum magnetic energy). The working temperature of about $470 \mathrm{~K}$.

Table 1. Comparative characteristics of the magnets of the systems Sm-Co, Fe-Nd-B and Fe-Nd-C.

\begin{tabular}{|c|c|c|c|c|c|}
\hline Connection & $\mathrm{T}_{\mathrm{K}}, \mathrm{K}$ & $\mathrm{Is}, \mathrm{T}$ & $\mathrm{B}_{\mathrm{r}}, \mathrm{T}$ & $\begin{array}{c}\mathrm{H}_{\mathrm{A}}, \\
\mathrm{MA} / \mathrm{m}\end{array}$ & $\begin{array}{c}(\mathrm{BH})_{\max }, \\
\mathrm{kJ} / \mathrm{m}^{3}\end{array}$ \\
\hline $\mathrm{SmCo}_{5}$ & 1020 & 1,14 & 0,77 & 1,3 & 140 \\
\hline $\mathrm{Nd}_{2} \mathrm{Fe}_{14} \mathrm{C}$ & 535 & 1,5 & 0,8 & 7,6 & 450 \\
\hline $\mathrm{Nd}_{2} \mathrm{Fe}_{14} \mathrm{~B}$ & 585 & 1,6 & 1,2 & 5,4 & 512 \\
\hline
\end{tabular}

Technical characteristics of the magnets:

1. Magnetic induction $\mathrm{Br} \geq 0.9 \mathrm{~T}$.

2. The coercive force $\mathrm{HC} \geq 600 \mathrm{kA} / \mathrm{m}$.

3. Operating temperature $\mathrm{T} \geq 493 \mathrm{~K}$.

The calculation of magnetic forces in the magnetic damper. Informed by the results of the research supports damper with a permanent magnet the Bekkers were made the following conclusions: by increasing the radius of the support its capacity increases linearly, and the weight of the shaft increases with the square. That is, under certain conditions, the bearing will compensate only the weight of the shaft. Therefore, the shaft must be run empty and the inner ring of the bearing - minimal [12-20].

To calculate the discharge power was used the following formula:

$$
F=\frac{\mu_{0} \cdot J^{2} \cdot l \cdot(r+x / 2)}{2} \cdot e^{-\frac{\pi \cdot x}{d}} \cdot \sin \varphi
$$

Magnetic saturation can be defined as:

$$
J=\frac{B}{\mu_{0}}-H
$$

In total, this design uses magnets 390 . The size of the magnets that are used in design, $6 \times 12 \times 16 \mathrm{~mm}$, height $6 \mathrm{~mm}$, the working part of the magnet $12 \times 16 \mathrm{~mm}$, thus this plane can be divided into 12 elementary magnets of square section. Thus, for a single magnet, the value of the discharge power obtained by the formula 1 , should be increased in 12 times.

\begin{tabular}{|c|c|c|}
\hline Magnetic system & The coercive force, $\mathrm{H}_{\mathrm{C}}, \mathrm{kA} / \mathrm{m}$ & $\begin{array}{l}\text { Residual induction, } \mathrm{Br} \text {, } \\
\quad \mathrm{T}\end{array}$ \\
\hline Magnetoplasma composition $\mathrm{Nd}_{15,2} \mathrm{Fe}_{74,99} \mathrm{Cu}_{1,57} \mathrm{~B}_{6,5} \mathrm{C}_{0,51} \mathrm{Ti}_{1,38}$ & 1320 & 0,79 \\
\hline $\begin{array}{l}\text { Anisotropic magnet composition } \mathrm{Nd}_{15,2} \mathrm{Fe}_{75,5} \mathrm{Cu}_{1,57} \mathrm{~B}_{6,5} \mathrm{C}_{0,17} \mathrm{Ti}_{1,38} \\
\text { after TH }\end{array}$ & 1260 & 1,125 \\
\hline Plate magnets KS-37 & 1300 & 0,77 \\
\hline Rosenteich force for the minimum values of $\mathrm{H}_{\mathrm{C}}$ and $\mathrm{Br}$ & 600 & 0,9 \\
\hline
\end{tabular}

Table 2. Magnetic properties [21-24].

Using the data in table 2, determined by the discharge power according to the formula (1). To compute the dependence of the force from the magnitude of the gap in the magnetic damper, it was believed that the sine of the maximum angle of rotation [25].

It is known that the smaller the gap in the damper, the greater razanajato power can be achieved [5,26-32]. However, the features of production do not allow to reduce the gap to a minimum. In the proposed design, the clearance is 1 $\mathrm{mm}$. figure 7 shows the dependence razanajato forces from the gap in the magnetic damper.

In Fig. 5-7 shows the dependence razanajato power from step razanajato (axial) forces from the gap and radial forces from clearance for sintered under the initial pressure of 12 $\mathrm{MPa}$ and a temperature of $1023 \mathrm{~K}$ magnets of the composition $\mathrm{Nd}-\mathrm{Fe}-\mathrm{B}$ doped with $\mathrm{Cu}, \mathrm{C}$, Ti in the magnetic damper.

Radial support stiffness is calculated according to the following formula:

$$
C=\frac{F}{x}
$$

The specific lift force per unit surface is calculated by the following formula:

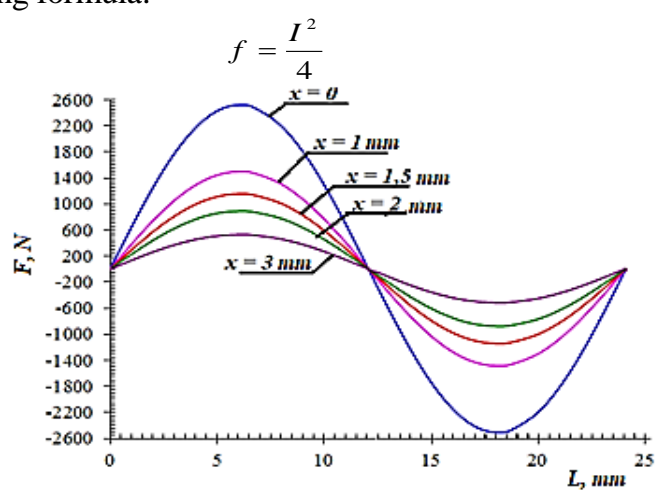

Fig. 5. Dependence razanajato (axis) from the force of the step sintered under the initial pressure of $12 \mathrm{MPa}$ and a temperature of $1023 \mathrm{~K}$ magnets of the composition $\mathrm{Nd}_{15,2} \mathrm{Fe}_{74,99} \mathrm{Cu}_{1,57} \mathrm{~B}_{6,5} \mathrm{C}_{0,51} \mathrm{Ti}_{1,38}$.

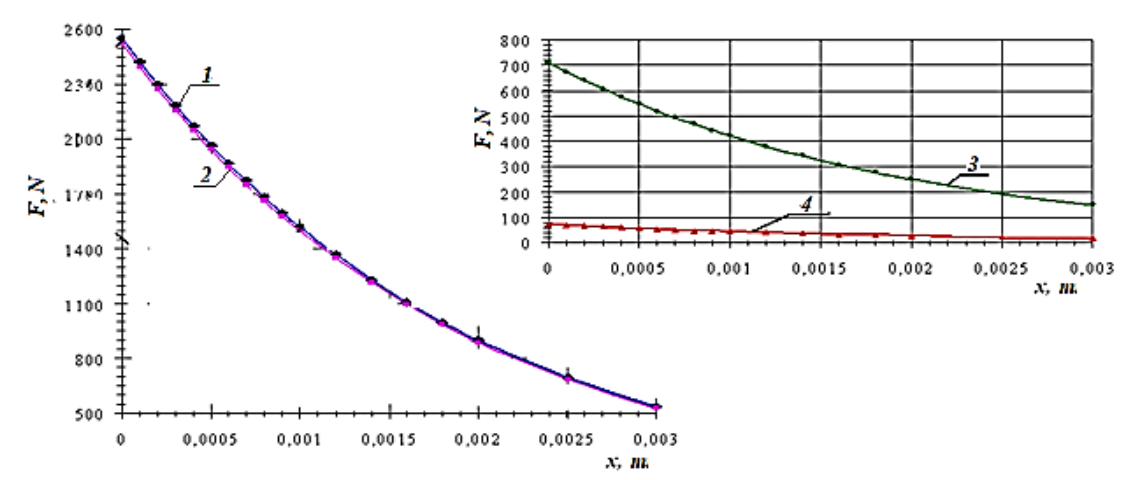

Fig. 6. Dependence razanajato (axial) forces from the gap in the magnetic damper:

1 - Baked under an initial pressure of $12 \mathrm{MPa}$ and a temperature of $1023 \mathrm{~K}$ magnets of the composition $\mathrm{Nd}_{15,2} \mathrm{Fe}_{74,99} \mathrm{Cu}_{1,57} \mathrm{~B}_{6,5} \mathrm{C}_{0,51} \mathrm{Ti}_{1,38 \mathrm{i}}$; 2 - Plate magnets KS-37; 3 - Anisotropic magnets of the composition $\mathrm{Nd}_{15,2} \mathrm{Fe}_{75,5} \mathrm{Cu}_{1,57} \mathrm{~B}_{6,5} \mathrm{C}_{0,17} \mathrm{Ti}_{1,38}$ after HT; 4 - Rosenteich power for the minimum values of $\mathrm{HC}$ and $\mathrm{Br}$. 

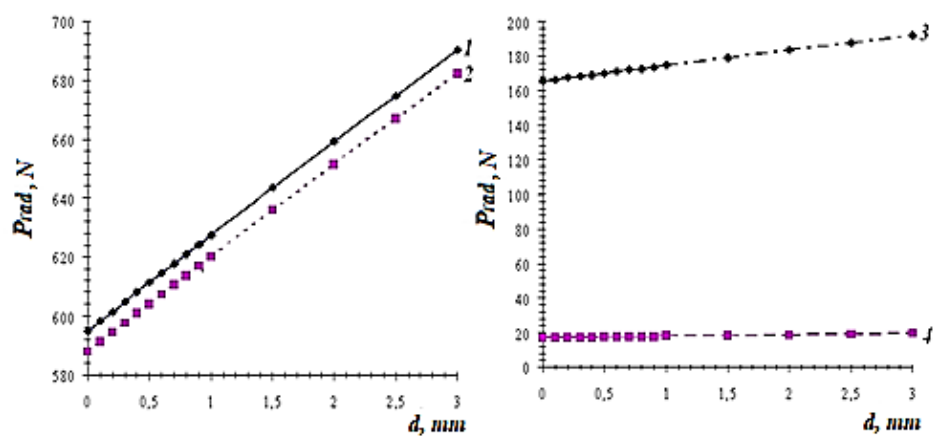

Fig. 7. the dependence of the radial forces from the gap in the magnetic damper:

1 - Baked under an initial pressure of $12 \mathrm{MPa}$ and a temperature of $1023 \mathrm{~K}$ magnets of the composition $\mathrm{Nd}_{15,2} \mathrm{Fe}_{74,99} \mathrm{Cu}_{1,57} \mathrm{~B}_{6,5} \mathrm{C}_{0,51} \mathrm{Ti}_{1,38}$; 2 - Plate magnets KS-37; 3 - Anisotropic magnets of the composition $\mathrm{Nd}_{15,2} \mathrm{Fe}_{75,5} \mathrm{Cu}_{1,57} \mathrm{~B}_{6,5} \mathrm{C}_{0,17} \mathrm{Ti}_{1,38}$ after $\mathrm{HT}$; 4 - Rosenteich power for the minimum values of $\mathrm{HC}$ and $\mathrm{Br}$.

Tab. 3 presents the unit values for the lift force, which is calculated by the formula (4) for different types of magnets.

Table 3. values of specific lift force per unit surface of the magnet.

\begin{tabular}{|c|c|}
\hline Magnetic system & Specific lifting force, $\mathrm{f}, \mathrm{kN} / \mathrm{mm}^{2}$ \\
\hline Magnetoplasma composition $\mathrm{Nd}_{15,2} \mathrm{Fe}_{74,99} \mathrm{Cu}_{1,57} \mathrm{~B}_{6,5} \mathrm{C}_{0,51} \mathrm{Ti}_{1,38}$ & 119,377 \\
\hline $\begin{array}{c}\text { Anisotropic magnet composition } \mathrm{Nd}_{15,2} \mathrm{Fe}_{75,5} \mathrm{Cu}_{1,57} \mathrm{~B}_{6,5} \mathrm{C}_{0,17} \mathrm{Ti}_{1,38} \\
\text { after TH }\end{array}$ & 33,178 \\
\hline Plate magnets KS-37 & 117,973 \\
\hline Rosenteich force for the minimum values of $\mathrm{H}_{\mathrm{C}}$ and $\mathrm{Br}$ & 3,396 \\
\hline
\end{tabular}

In Fig. 8 shows the dependence of the radial stiffness of the support from the gap in the magnetic damper.

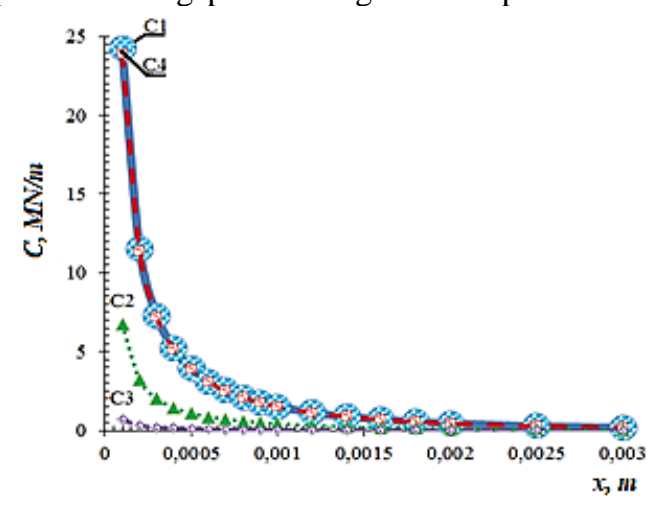

Fig. 8. Dependence of the radial stiffness of the support from the gap in the magnetic damper:

$\mathrm{C} 1$ - Baked under an initial pressure of $12 \mathrm{MPa}$ and a temperature of $1023 \mathrm{~K}$ magnets of the composition

$\mathrm{Nd}_{15,2} \mathrm{Fe}_{74,99} \mathrm{Cu}_{1,57} \mathrm{~B}_{6,5} \mathrm{C}_{0,51} \mathrm{Ti}_{1,38}$; $\mathrm{C} 2$ - Anisotropic magnets of the composition $\mathrm{Nd}_{15,2} \mathrm{Fe}_{75,5} \mathrm{Cu}_{1,57} \mathrm{~B}_{6,5} \mathrm{C}_{0,17} \mathrm{Ti}_{1,38}$ after HT; $\mathrm{C} 3$ - Rosenteich power for the minimum values of $\mathrm{HC}$ and $\mathrm{Br}$; $\mathrm{C} 4$ - Plate magnets KS-37.

Thus, the proposed design fan shaft with magnetic damper and the analysis of magnetic materials that can be used in the damper based on structural features. It is shown that the maximum stiffness of the damper and taking into account the cost of finished products the most successful are the magnets made from the alloy $\mathrm{Nd}_{15,2} \mathrm{Fe}_{74,99} \mathrm{Cu}_{1,57} \mathrm{~B}_{6,5} \mathrm{C}_{0,51} \mathrm{Ti}_{1,38}$. It is also shown that such a design of the support does not require the traditional oil supply for cooling of the bearing and is devoid of typical defects between the bulk of the supports.

\section{Conclusions}

1. The proposed design fan shaft with magnetic damper that had the task of testing the possibility of applying this type of damper extra support for long shaft engines. Such a design of the support does not require the traditional oil supply for cooling of the bearing and is devoid of typical defects mevalonic supports.

2. The scheme tests the magnetic damper, the calculated discharge power for different types of magnetic systems.

3. The analysis of magnetic materials that can be used in the damper based on structural features. Analyzed three systems: Sm-Co, Fe-Nd-B and Fe-Nd-C, from which we can conclude that magnetic characteristics of the most printlevel may be the system Fe-Nd-B.

4. Developed the design of the fan shaft with magnetic damper is at the stage of experimental work to determine the effect of magnetic field on the details that surround the damper in the first place, on the parts of the bearing and the efficiency of damping.

\section{REFERENCES}

1. Martynenko, G.Y. (2007) Determination of the stiffness characteristics of the radial magnetic bearings in two circular permanent magnet [Opredelenie zhestkostnykh kharakteristik radialnykh magnitnykh podshipnikov na dvukh koltsevykh postoiannykh magnitakh] / Visnyk NTU «HPI». Tem. vyp. «Dynamika i micnist' mashyn»Bulletin of NTU "KHPI". The. vol. "Dynamics and strength of machines", 38, 83-95. [in Rus]

2. Metlin, V.B. (1968) Magnetic and magnetohydrodynamic support [Magnitnye i magnitogidpodinamicheskie opory). Moscow: Energy. [in Rus]

3. Demkin, N.B. \& Bolotov, A.N. (1980) The study of axial magnetic bearings [Issledovanie aksial'nyh magnitnyh podshipnikov] / Trenie i iznos - Friction and wear, 1(1), 697-704. [in Rus]

4. Sarychev, A.P. \&Matveichuk P.A. (1996) Experience of develop- ment and manufacture of electromagnetic bearings for the oil and gas industry [Opyt razrabotki, izgotovlenija jelektromagnitnyh podshipnikov dlja neftegazovoj promyshlennosti] / Kompressornaja tehnika i pnevmatikaju - Compressors and pneumatical, 3-4(1213), 107-109. [in Rus]

5. Shorr, B.F. \& Melnikov, G.V. (1988) The analysis of structures by the method of direct mathematical modelling [Raschet konstrukcij metodom prjamogo matematicheskogo modelirovanija]. Moscow: Mashinostroenie. [in Rus]

6. Constructive-circuit design [E. source]. - Mode of access URL: reshenie. [in Rus]

7. Petrova L. G., Chudina A. V., Ostroukh A.V. (2007) Mechanical properties of metals. Plastic deformation and recrystallization: a http://www.aviagazoturbina.ru/index.php/konstruktivno-shemnoe- 
study guide to multimedia educational publishing, Moscow: MADI(GTU). [in Rus]

8. Shaikhutdinov A. \& Sarychev A. (2001) Magnetic suspension for flexible rotors compress-litters of gas pumping units. Manufacturers offer compressors and compressor equipment, 180-183. [in Rus]

9. Gulyaeva T. V., Kolomoets A. E., Gulyaev V. S., Behara N. V. (2007) Obtaining magnetic materials needed for the magnetic dampers of aircraft engines, Bulletin of the engine. Zaporozhye JSC "Motor Sich", № 2, 189 - 193. [in Rus]

10. Bolotov A. N. \& Fucking V. L. (2008) Tribology magnetoactive bearings: monograph. Tver: TSTU. [in Rus]

11. Patent No. RU2287729C1. Electromagnetic damper [E. source] / E. V. Sidorov, G. S. Tyukavin. - Mode of access URL: http://www.findpatent.ru/patent /228/2287729.html. [in Rus]

12. The supremely D. A. Magnetic system of a synchronous electrical machines with permanent magnets and high speed: the abstract Diss...Cand. tech. nauk: spets. - 05.09.01 "Electrical engineering and electric apparatus" / Citin Dmitry Medvedev. - M.: MAI, 2009. - 24 sec. [in Rus]

13. Bearings SKF: General catalogue. - SPb., 1989. - 976 p. [in Rus]

14. Zhuravlev Yu. N. (2003) Active magnetic bearings: Theory, calculation, application. SPb.: Polytechnic. [in Rus]

15. Petzold O. (2006) Hybridmagnete für einen magnetisch gelagerten Rundtisch. Technische mechanik Band 26, Heft 2, p. 85-86. [in German]

16. Neumann L. G. Theoretical foundations of electrical engineering / L. G. Neumann, K. S. Demirchyan. - Leningrad: Energoizdat, 1981. - 250 p. [in Rus]

17. Sharov V. S. Peculiarities of calculation of magnetic suspension of rotors for high speed electric motors / U. S. Sharov. - M.: MPEI, 1982. -84 p. [in Rus]

18. Vereshchagin V. P. Mathematical model of magnetic bearing / U. P. Vereshchagin, V. A. Klabukov // electromechanics. Proceedings VNIIEM, 2009. - T. 112. - S. 17 - 22. [in Rus]

19. Mikhailin V. (2007) Permanent magnets on the basis of bonded for electronic equipment (development of technology of obtaining, properties and application): abstract. dis. kand. technical Sciences: 05.11.14 "Technology of instrument making" [E. source]. M., Mode of access URL: http://www.dissercat.com/content/ postoyannye-magnity-na-osnove-magnitoplastov-dlya-priborovelektronnoi-tekhniki-razrabotka-t. [in Rus]

20. Zolotarevskii V. S., (1998) Mechanical properties of metals [textbook for high schools], [3rd ed., Rev.]. - M.: MISIS. [in Rus]

21. Brekharya G. P., Kharitonova E. A., Gulyaeva T. V. (2014) Properties of the permanent magnets $\mathrm{Nd}-\mathrm{Fe}-\mathrm{B}$ alloy with $\mathrm{Cu}, \mathrm{Ti}, \mathrm{C}, \mathrm{ob}$ tained by a powder method or sintering of the films at high pressure. Progress in physics of metals. - K.: IMF. T. 15. P. 35-53. [in
Rus]

22. Pat. 105308 Ukraine, IPC H01F 1/057 H01F 1/053 B22F 3/12. Material for rdcenabled postijno magneto the method of Yogo producing / Brekharya G. P., Kharitonov, O. A., V. A. Dechtiarenko, Gulyaeva, T. V.; salnik patentovannym Kyiv, Institute of metallic im. G. V. Kurdyumov of NAS of Ukraine. No. a 201302023; stated. 19.02.2013; publ. 25.04.2014, bull. No. 8 [in Ukr]

23. Pat. on corino model 92390 Ukraine, IPC H01F 1/00 H01F 1/053 $\mathrm{H} 01 \mathrm{~F} 1 / 057$. The method of darianna postijno magneto on snow splavu $\mathrm{Nd}-\mathrm{Fe}-\mathrm{B} /$ Brekharya G. P., Gulyaeva T. V., Kharitonova O. A., Gulev V. I., Gnezdilov V. O., Of Device T. I., Litvinenko, Y. M.; Savnik patentovannym Kyiv, Institute of metallic im. G. V. Kurdyumov of NAS of Ukraine. no u 2014 03132; stated. 28.03.2014; publ. 11.08.2014, bull. No. 15. [in Ukr]

24. Gulyaeva T. V. (2015) Proposed rational leguana Reimu Spinna econome-legovini Shvidko hologenic splavu Nd-Fe-B-Ti-C-Cu for paviment magnetic feature: dis. on zdobuttya Sciences. Stupina candidate. tech. SC.: spec. 05.16.01 "Metaloplast Termona obrobka metalu" / T. V. Gulyaeva -Zaporizhzhya, 175 p [in Ukr]

25. Gulyaeva T. V., Tatarchuk O. V., Gulyaeva L. V. (2013) Magnetogorsk material magnetic dempfer avazbekov. X International scientific and technical conference "Progresive technology gitto cycle avecina dvigun energetichnih installations": dopoda tezi, (Alushta, Krim, Ukraine, the 23-28 of September 2013). - Zaporozhye: OJSC "Motor Sich", P. 144-147. [in Ukr]

26. Patent No. EN 2280876 C1 Acceleration Sensor [E. source] / E. L. Mezhirich, E. A. Ivanovskii, V. A. Kurtukov [and others]. - Mode of access URL: http://www.findpatent.ru/patent/ 228/2280876.html. [in Rus]

B27. olotov A. N. \& Xrenov V. L. (1995) Tribology of bearings and guides of the slide with the magnetic unloading. Friction and wear. T. 16. No. 6. P. 1048 - 1070. [in Rus]

28. Izotov A. D. (1982) Calculation of unsteady-loaded bearings. L.: Engineering. [in Rus]

29. Bolotov A. N., Novikov V. V., Zelenkov S. D. (2007) Magnitosloe the interaction of highly coercive permanent magnets for the bearing support: monograph. Tver: TSTU. [in Rus]

30. Krinchik, G. S. (1976) Physics of magnetic phenomena. M.: Izd-vo Mosk. University press. [in Rus]

31. Tolstoy D. M., Borisova G. A., Grigorova S. R. (1971) The Role of normal variation in normal direction during friction. About the nature of friction of solids. Minsk: Nauka. [in Rus]

32. Read more about gas turbine engines of the family of D-436. State enterprise "Zaporozhye machine-building design Bureau "Progress" named after academician A. G. Ivchenko [E. source]. Mode of access URL: http://www.zmkb.com /welcome.do?id=146 guidance for those operating. [in Rus]

\section{Магнитний демпфер для авиадвигателя Д-436т \\ Т. В. Гуляева, О.В. Татарчук, Л. В. Гуляева}

Аннотация. В статье рассматривается конструкция магнитного демпфера, который предназначен для устранения проблемы возникновения резонанса, приводящего к вибрации вала на больших оборотах. При создании двигателей большой степени двухконтурности с высокими частотами вращения роторов чрезвычайно большое значение имеют вопросы динамики. Наиболее эффективным средством снижения уровня вибраций и динамических нагрузок в узлах двигателей является применение демпферных опор. Для окончательного определения эффективности типа демпфера, которыв может быть выбран и рассчитан для данного двигателя, необходимо выполнить экспериментально-доводочные работы. При доводке двигателя Д-436Т1 (проведение специальной проверки по колесу вентилятора) при оборотах вентилятора 5900 ... 6100 об/мин возникали повышении вибрации двигателя на частотах ротора вследствие резонансных колебаний вала вентилятора. Эти колебания вызвали изгиб вала вентилятора и касания его об статорные и роторные детали компрессора низкого давления. Изменение конструкции вала вентилятора для устранения резонанса было невозможным. Добалансировка колеса вентилятора и имеющийся в конструкции вентилятора упруго-масляный демпфер не обеспечивали устранения резонанса. Для решения проблемы была разработана конструкция магнитного демпфера, которая позволяет не менять технологию сборки двигателя и обеспечивает его работоспособность на всех режимах работы. Проведен анализ магнитных материалов, которые могут быть использованы в данном демпфере, исходя из конструктивных особенностей и обеспечения максимальной жесткости демпфера. Проанализированы три системы: Sm-Co, Fe-Nd-B и Fe-Nd-C, из которых можно сделать вывод, что по магнитным характеристикам наиболее подходящей может быть система Fe-Nd-B. На данный момент разработана конструкция вала вентилятора с магнитным демпфером находится на стадии экспериментальных работ с целью определения влияния магнитного поля на детали, которые окружают данный демпфер, в первую очередь, на детали шарикоподшипника и эффективность демпфирования.

Ключевые слова: магнитный демпфер, осевая сила, радиальная сила, жесткость демпфера, коэриитивная сила, остаточная индукция. 